\title{
How do cattle's preferences vary according to forage accessibility ?
}

\author{
B Dumont, X Boivin, M Petit
}

INRA, Adaptation des Herbivores aux Milieux, Theix, 63122 St-Genè-Champanelle, France

We used an operant procedure to study in wellcontrolled conditions the choices of cattle between a good quality forage offered in limited quantities and a poor quality one available ad libitum. We assessed the response of animals either fed or deprived of food to changes in good forage accessibility.

Nine 1-year-old Charolais heifers (LW : $362 \mathrm{~kg}$ ) were used. When not tested, they were fed a natural mountain pasture hay and a concentrate which accounted for $50 \%$ of energy supply. When tested, they were given a poor quality fescue hay (CP : $8.4 \%$; CF : $34.9 \%$ ) and a good-quality regrowth (CP: $12.7 \%$; CF : $28.0 \%$ ). After 22 ten-minute sessions, the heifers were able to press a button with their muzzle to get the good hay from an operant feeding device. In three successive 1-month periods, they had to press the button 3,8 and 5 times respectively to be rewarded (good hay available for 15 seconds). In each period, the good hay was first offered alone for 5 sessions to teach the animals the press number/food reward. The poor hay was then introduced in a trough and 3 choice sessions were held before recordings began. Choices were recorded on Monday, Wednesday and Friday mornings in the following two weeks. Every day, the animals were twice tested for 5 minutes. In each period, every animal was tested in three fasting regimes. When fasted, the animals had either received $50(\mathrm{~F} 24)$ or $100 \%(\mathrm{~F} 16)$ of daily feed allowance the day before and were not fed before measurements. When not fasted (F0), they had received their daily diet the day before, and were fed $0.75 \mathrm{~kg}$ hay and $1.4 \mathrm{~kg}$ concentrate before measurements. The effects of press number/food reward, fasting and individual animals were considered in an analysis of variance. The Bonferroni t test was used to detect differences between treatments.

Preference for good hay (time spent working for + feeding) decreased linearly with the increase of press number/reward $(P<0.001)$. There were large variations (12 to $82 \%$; $\mathrm{P}<0.001)$ between individual animals, and the interaction between press number and individual was significant $(P<0.001)$. Fasting did not influence preference for good hay, but slightly increased the time spent feeding on poor hay $(P<0.05)$, without any interaction with press number.

This study confirms that cattle accept to switch on poor quality forages when the accessibility of better ones decreases. This was already observed when the quantity of good hay rewarding a walk (Dumont and Petit 1995, Appl Anim Behav Sci, submitted) or when the height of sward patches was changed, indicating that this ability should be rather independent of the way the accessibility varies. Conversely, the preferences of cattle are only little affected by fasting, at least in short-duration tests (Dumont et al, 1995, Appl Anim Behav Sci, in press).

\begin{tabular}{lccc} 
Press number/reward & 3 & 5 & 8 \\
\hline Good hay (\%) & $73^{\mathrm{a}}$ & $54^{\mathrm{b}}$ & $31^{\mathrm{c}}$ \\
Poor hay (\%) & $25^{\mathrm{a}}$ & $44^{\mathrm{b}}$ & $67^{\mathrm{c}}$ \\
Idling (\%) & $2^{\mathrm{a}}$ & $2^{\mathrm{a}}$ & $2^{\mathrm{a}}$ \\
Presses in $10 \mathrm{~min}$ & $12^{\mathrm{a}}$ & $7.6^{\mathrm{b}}$ & $3^{\mathrm{c}}$ \\
Fasting regime & $\mathrm{F}$ & $\mathrm{F} 16$ & $\mathrm{~F} 24$ \\
\hline Good hay (\%) & $55^{\mathrm{a}}$ & $53^{\mathrm{a}}$ & $50^{\mathrm{a}}$ \\
Poor hay (\%) & $41^{\mathrm{a}}$ & $45^{\mathrm{ab}}$ & $50^{\mathrm{b}}$ \\
Idling (\%) & $4^{\mathrm{a}}$ & $2^{\mathrm{b}}$ & $0^{\mathrm{b}}$ \\
Presses in 10 min & $7.8^{\mathrm{a}}$ & $7.7^{\mathrm{a}}$ & $7.5^{\mathrm{a}}$ \\
\hline
\end{tabular}

Means with different letters are significantly different at $P<0.05$ 